\title{
CARBONATE STRATA OF THE CRETACEOUS OF NORTH-WESTERN BLACK SEA SHELF AND THEIR OIL-AND-GAS POTENTIAL
}

\section{A.V. Ryabukha}

\section{КАРБОНАТНІ ПОРОДИ КРЕЙДИ ПІВНІЧНО-ЗАХІДНОГО ШЕЛЬФУ ЧОРНОГО МОРЯ I ЇХ НАФТОГАЗОВИЙ ПОТЕНЦІАЛ}

\section{A.В. Рябуха}

Carbonate strata of the Cretaceous sediments of north-western Black Sea shelf is represented different lithological types, such as limestones, siliceous limestones and siliceous marls. Microscopical analysis permit to define more accurately material and mineral constitutions and structural features. This information is base for reconstructions of lithofacies formation conditions of carbonate strata. The half of world oil production resources belongs to carbonate strata, therefore theirs next researches have practical importance for Ukraine power economy.

Key words: carbonate strata, reservoir, the Cretaceous, Black Sea shelf.

Карбонатні породи крейдових відкладів північно-західного шельфу Чорного моря представлені різними літологічними типами - вапняками, кременистими вапняками та кременистими мергелями. Мікроскопічне вивчення дозволяє уточнювати речовинний та мінеральний склад і структурні особливості порід, на яких базуються реконструкції літологофаціальних умов утворення карбонатних порід. Половина запасів світового видобутку нафти припадає на карбонатні породи, тому їх дослідження має велике практичне значення для енергетичного комплексу України.

Ключові слова: карбонатні породи, колектор, крейдовий період, шельф Чорного моря.

\section{ВСТУП}

Україна перебуває в стані енергетичної кризи, і зараз дуже відчутною є недостатня кількість власних запасів енергоносіїв. Ми знаходимося на порозі великих змін - освоєння нафтогазового потенціалу шельфу Чорного моря. Вже давно доведено, що на шельфі Чорного моря є запаси вуглеводнів. Вже проведені численні геофізичні дослідження і пошукове буріння, а на деяких структурах іде видобування. Але, на жаль, це лише перші кроки, а промислове видобування ще попереду.

\section{РАЙОН РОБІТ, МЕТОДИ ТА ОБ'ЄКТ ДОСЛІДЖЕННЯ}

На початкових етапах вивчення геологічної будови північно-західного шельфу Чорного моря базувалося за даними буріння десятка свердловин, які розкидані по всій акваторії, і на основі кореляції з відкладами суміжного суходолу. Тоді було встановлено, що породи нижньокрейдового періоду на шельфі представлені здебільшого піщано-глинистими утвореннями, причому розвиток алевритопіщанистих порід прогнозується головним чином в нижній ї̈ частині, сформованій в початковий період трансгресії ранньокрейдового моря. В верхній частині, яка відповідає максимуму трансгресії, переважають глини і мергелі. В свою чергу, розріз верхньої крейди складений в основному вапняками з підпорядкованими їм мергелями, рідко спостерігається збагачення вапняків глинистим і піщаноалевролітовим матеріалом.

На північно-західному шельфі Чорного моря виділяють нижньокрейдовий, верхньокрейдово-палеоценовий і майкопський нафтогазоносні комплекси [1]. Причому регіонально нафтогазоносні нижньокрейдові відклади розглядаються як один з основних об'єктів пошуків покладів вуглеводнів у межах півдня України і прилягаючих акваторій [2].

Лабораторні дослідження передбачають уточнення даних макроскопічного опису карбонатної породи відносно загальних рис її речовинного складу, структури і частково текстури, з одночасним виявленням тих особливостей її складу і будови, які не можуть бути встановлені візуально. Крім того, лабораторними методами визначаються різні фізичні і колекторські властивості карбонатної породи, насамперед її пористість і проникність, а також щільність, залишкова водонасиченість та ін., важливі для встановлення ії можливих колекторських особливостей [4].

Хоча обов'язкового, чітко визначеного набору видів аналізів для лабораторних досліджень породи не існує, але треба неодмінно дотримуватися відомої послідовності лабораторного вивчення зразка. Вона передбачає такий ряд дій: передача частини зразка в лабораторію фізики пласта на визначення 
пористості, проникності, щільності та ін.; виготовлення шліфів с попереднім переглядом зразка під люмінесцентною лампою; забарвлення шліфа алізарином червоним і подальше вивчення його під мікроскопом (одночасно може виконуватися імерсійне визначення карбонатних мінералів породи).

Послідовність виконання подальших аналізів може бути різною [4], тому що вони проводяться в різних лабораторія і можуть здійснюватися одночасно: визначення нерозчинного залишку; виділення нерозчинного залишку з подальшим механічним аналізом і виділенням фракцій для вивчення хімічного складу глинистої фракції (<0,01 мм), мінерального складу тонкої глинистої фракції $(<0,001 \mathrm{mм})$ рентгенометричними методами, мінерального складу алевритової і дрібнопіщаної фракцій методом імерсійного аналізу; хімічний аналіз карбонатного матеріалу породи (із солянокислої витяжки); визначення мінерального складу карбонатного матеріалу породи методами термічного і рентгенометричного аналізів; спектральний аналіз; електронномікроскопічне вивчення породи; ізотопний аналіз карбонатів; вивчення органічної речовини (в тому числі бітумів), яка міститься в породі методами напівкількісного люмінесцентно-капілярного аналізу, в спеціально виготовлених шліфах під люмінесцентним мікроскопом, методами хіміко-бітумінологічного аналізу; визначення абсолютного віку.

Про велике значення карбонатних порід як колекторів нафти свідчить те, що на ці породи припадає половина чи більше світового видобутку нафти. Найбільше скупчення великих родовищ нафти в світі знаходиться на Середньому Сході, де нафта здебільшого видобувається з покладів мезозойських і кайнозойських карбонатних колекторів. Найбагатші поклади нафти приурочені до крейдових вапняків в західній частині Венесуели і в багатьох крупних родовищах Мексіки. В США крейдові і юрські карбонатні породи слугують нафтоносними резервуарами в ряді місць Прибережної Атлантичної рівнини. Повсюдно в США нафтові поклади тяжіють до палеозойських карбонатних порід - в західній частині Техасу, в Серединноконтинентальних родовищах Канзасу, Оклахоми і північної частини Техасу, в ряді районів Скелястих гір, а також на численних невеликих полях Мічігану, Індіани, Огайо, Іллінойсу і Кентуккі. Доломітизовані девонські рифи на заході Канади вміщують великі поклади нафти і газу, а міссісіпські вапняки Саскачевану і сусідньої Північної Дакоти - найбагатші поклади нафти. Безсумнівно, що поклади нафти в карбонатних породах мають велике практичне значення, що стимулює вивчення колекторських властивостей цих порід.

\section{РЕЗУЛЬТАТИ ДОСЛІДЖЕННЯ ТА ЇХ АНАЛІЗ}

Крейдові відклади північно-західного шельфу Чорного моря стали доступними для вивчення в 70-80-і роки минулого сторіччя, коли в цій частині акваторії почалось буріння глибоких свердловин. За даними проведених досліджень відклади верхньої крейди представлені доволі одноманітною товщею вапняків і мергелів.

Питанням літології крейдових відкладів північно-західного шельфу та дослідженням карбонатних порід займалась М.Д. Крочак [3]. За результатами хімічного аналізу були запропоновані такі літологічні типи карбонатних порід: вапняки $\left(\mathrm{CaCO}_{3}-75-100 \%\right)$, кременисті вапняки $\left(\mathrm{CaCO}_{3}-50-75 \%\right)$, кременисті мергелі $\left(\mathrm{CaCO}_{3}-25-50 \%\right)$. За структурними ознаками вапняки поділяються на такі різновиди:

1. Вапняки органогенні (вміст черепашок понад 50\%) - пітонелові (кальцисферуліди), радіолярієві, форамініферові.

2. Вапняки органогенно-детритусові (вміст черепашок і детритусу більше 50\%) - спонголітові, форамініферові.

3. Вапняки нормально-зернисті з вмістом органічних решток 10-40\% - форамініферо-кальцисферулідові, форамініферо-радіолярієво-спонголітові.

4. Вапняки нормально-зернисті пелітоморфні (вміст органічних решток менше 10\%) - крейда, крейдоподібні, мікрозернисті.

Головним компонентом карбонатних порід верхньої крейди є карбонат кальцію, вміст якого в породах змінюється від 20 до 99\%. В товщі верхнього маастрихту вміст СаСОЗ дуже мінливий і становить 28-92\%, в той час як відклади нижнього маастрихту-турону характеризуються відносно постійними показниками вмісту $\mathrm{CaCO}_{3}$, що дорівнюють 80-99\%. Причому максимальні значення 96-99\% відповідають коньяк-туронським породам.

Для відкладів сеноману-нижнього маастрихту середні значення карбонатності по площі змінюються в невеликих межах - 10-20\%, що свідчить про приблизно схожі умови осадконакопичення на 

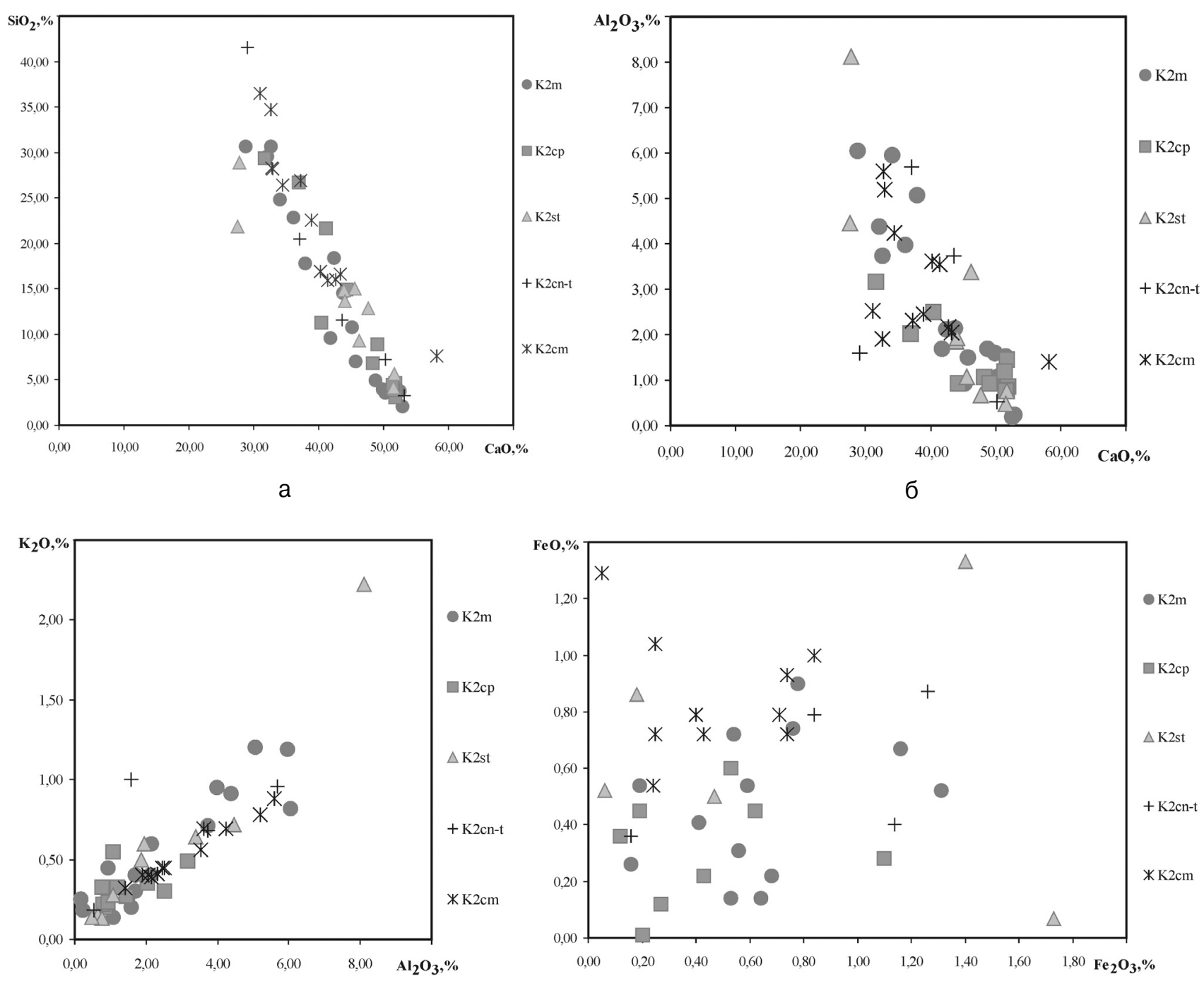

B

$\Gamma$

Рис. 1. Графіки залежності вмісту різних компонентів в карбонатних породах верхньої крейди північнозахідного шельфу Чорного моря: $\mathrm{a}-\mathrm{SiO}_{2}$ від $\mathrm{CaO}$; б - $\mathrm{Al}_{2} \mathrm{O}_{3}$ від СаO; в $-\mathrm{K}_{2} \mathrm{O}$ від $\mathrm{Al}_{2} \mathrm{O}_{3}$; г - $\mathrm{FeO}$ від $\mathrm{Fe}_{2} \mathrm{O}_{3}$.

різних ділянках шельфу. Значна різниця значень карбонатності характерна для верхньомаастрихтських порід, яка стала результатом різних режимів осадконакопичення в умовах морського басейну, який скорочувався.

Другим за розповсюдженістю в породах $€ \mathrm{SiO}_{2}$. Його вміст в породах коливається від 3 до $62 \%$. Поширення $\mathrm{SiO}_{2}$ має протилежний характер розповсюдженню $\mathrm{CaO}$ (див. рисунок 1, а). Це закономірно, адже при зменшенні в породах кальциту в них зростає вміст опал-кристобаліту, тонкодисперсного кварцу і глинистих мінералів, складовою частиною яких $є$ кремнезем. За результатами аналізу можна стверджувати, що найменші значення $\mathrm{SiO}_{2}$, що дорівнюють 3-70\%, відносяться до вапняків маастрихту-турону, високі значення $\mathrm{SiO}_{2}$ (22-48\%), відповідають кременистим вапнякам сеноману, а максимальні значення $\mathrm{SiO}_{2}(54-62 \%)$, характерні для кременистих мергелів верхнього маастрихту.

Вміст в породах $\mathrm{Al}_{2} \mathrm{O}_{3}$ невеликий, змінюється від 0 до 8\%. На рисунку 1 б видно зворотну залежність між вмістом глинозему і СаO, яка виражена менш помітно, ніж для кремнезему. Мінімальні значення $\mathrm{Al}_{2} \mathrm{O}_{3}$ відмічені для вапняків маастрихту-турону, високі значення характерні для кременистих вапняків сеноману. А найбільші вмісти глинозему відповідають верхньомаастрихтським мергелям.

Значення вмісту $\mathrm{K}_{2} \mathrm{O}$ в породах відносно $\mathrm{CaO}$ змінюється аналогічно $\mathrm{Al}_{2} \mathrm{O}_{3}$ (див. рисунок 1, в). $\mathrm{K}_{2} \mathrm{O}$ $€$ обов'язковим компонентом глинистої фракції, тому його вміст збільшується разом з глиноземістю 


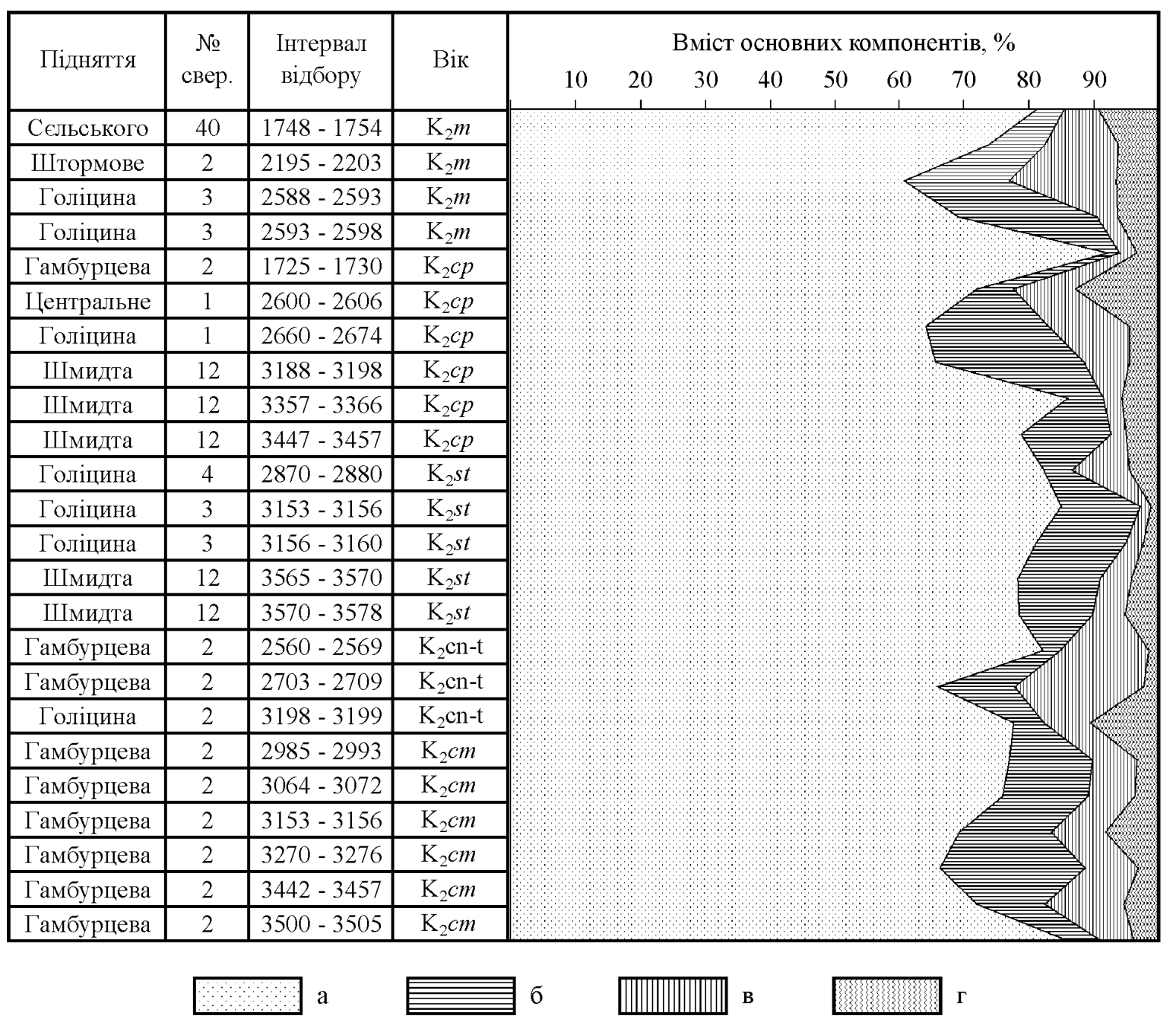

Pис. 2. Діаграма перерахунку хімічного складу карбонатних порід верхньої крейди північно-західного шельфу Чорного моря на мінеральні компоненти: а - кальцит; б - вільний кремнезем; в - глинисті мінерали; г - нерозчиний залишок

порід та зменшується при збільшенні карбонатності. Високі значення $\mathrm{K}_{2} \mathrm{O}$, які дорівнюють 0,70-2,68\%, відмічаються для мергелів верхнього маастрихту і сантону.

Вміст $\mathrm{MgO}$ і $\mathrm{Na}_{2} \mathrm{O}$ постійний, але невеликий; він збільшується в породах, які збагачені глинистим домішком. Виходячи з цього, можна припустити, що більша частина цих оксидів входить до складу глинистих мінералів. Це ще раз підкреслює низькомагнезіальність кальциту карбонатних порід верхньої крейди.

Абсолютні вмісти як окисного, так і закисного заліза в породах тим більші, чим менша їх карбонатність. У вапняках маастрихту, турону і сеноману відмічається переважання закисних форм заліза (див. рисунок 1, г). Це вказує на нестачу вільного кисню на дні басейну, який весь витрачався на розклад органіки і, як наслідок, присутність слабовідновних умов. Для мергелів верхнього маастрихту характерні близькі вмісти $\mathrm{FeO}$ і $\mathrm{Fe}_{2} \mathrm{O}_{3}$, які свідчать про накопичення осадків у нейтральних умовах.

Карбонатні породи верхньої крейди різною мірою збагачені глинистими мінералами. На рисунку 2 наведені результати перерахунку хімічного складу порід на основні мінеральні компоненти. В вапняках вміст глинистого мінералу не перевищує 10-15\% і розподіляється в породах нерівномірно. Самі ж вапняки найбільш чисті від домішок, а максимум глинистого матеріалу концентрується в глинистих прошарках та стилолітових швах, які перетинають вапнякові товщі. В мергелях глинистих мінералів понад 20-30\%, розподілені вони в породі рівномірно. Детальні дослідження показали, що глинисті мінерали представлені монтморилонітом, гідрослюдою, змішано-слойними утвореннями типу монтморилоніт-гідрослюда, каолініт. 
Поряд з глинистими мінералами в породах присутній ряд аутигенних мінералів, серед яких виділені кальцит, опал-кристобаліт, халцедон, кварц, пірит, глауконіт, барит і колофан [3]. До найбільш розповсюджених відносяться кальцит і мінерали групи кремнезему.

Нерозчинний залишок карбонатних порід верхньої крейди становить перші відсотки (вапняки) $75 \%$ (мергелі) від ваги породи. Значна частина залишку представлена фракціями пелітової розмірності 0,01-0,001 мм і менше 0,001 мм. Частка фракцій понад 0,01 мм незначна. Так, за даними гранулометричного аналізу, іх вага в вапняках сягає 0,02-0,04\% і рідко досягає 1\%, а в мергелях 0,03 - 3-10\% ваги породи. Встановлено, що велика частина виділених фракцій розміром понад 0,01 мм складена глинистими мінералами та утвореннями аутигенного походження - кременистими агрегатами, піритом, баритом. Уламкові матеріали становлять від перших відсотків до половини цих фракцій, а часто присутні в окремих зернах. Кількісний розподіл уламкових мінералів по розрізу непостійний.

Уламкові мінерали легкої фракції представлені, загалом, кутастими, погано окатаними зернами кварцу розміром 0,03-0,10 мм. Серед них зустрічаються також добре окатані уламки, що мають, як правило, більші розміри і досягають 1 мм в перетині. Кількість зерен кварцу неоднакова в породах різних підняттів. Окрім кварцу, в легкій фракції були відмічені в незначній кількості польові шпати (до 1-3\%). При цьому вони частіше відмічаються в тих породах, де вміст уламкових зерен вищий. Польові шпати представлені плагіоклазом, мікрокліном, ортоклазом і санідином, зерна яких мають кутасту форму, не обкатані і не змінені вторинними процесами.

Карбонатні породи збіднені на акцесорні мінерали. В деяких зразках вони взагалі не виявлені, в інших зустрічаються у вигляді одиничних зерен і лише інколи становлять 1\% важкої фракції. Відмічається деяке збільшення кількості і різноманітності акцесоріїв униз по верхньокрейдовому розрізу. Загалом, трапляються рідкісні зерна найбільш стійких до стирання мінералів циркону, гранату, турмаліну, рутилу й ільменіту. Рідше зустрічаються менш стійкі мінерали - моноклінні піроксени (діопсид, авгіт), амфіболи (рогова обманка, кумінгтоніт, актиноліт, глаукофан), егерин, біотит, дістен, епідот, силіманіт, кліноцоїзит, лейкоксен.

Невід'ємною частиною карбонатних порід крейди є бітумна речовина, яка широко розповсюджена в породах і надає їм темно-сіре забарвлення. Вона трапляється у вигляді паралельних сутурних ліній або знаходиться на контактах зерен кальциту і черепашок форамініфер. Характер розповсюдження бітумоїдів в карбонатних породах свідчить, що проникнення вуглеводнів в осадову товщу відбувалось в пізньому діагенезі і навіть після катагенетичної перекристалізації кальциту.

\section{ОБГОВОРЕННЯ РЕЗУЛЬТАТІВ}

Карбонатне осадконагромадження в межах Чорноморсько-Кримської епіпелагіалі розпочалося у пізньому альбі, максимального розвитку набуло у кампані-маастрихті і завершилося у ранньому палеоцені. В результаті була сформована потужна (500-4000 м) доволі одноманітна товща, складена широким за генезисом спектром карбонатних порід з підпорядкованими малопотужними прошарками кременистих та теригенних утворень. Відклади формувалися в трансгресивну (сеноман-кампан) та регресивну (кампан-ранній палеоцен) стадії седиментації в межах карбонатного палеошельфу 3 глибинами водойми 0-200 м.

Верхньокрейдові карбонатні нашарування району поряд з нижньокрейдовими та палеогеновими відкладами, являють собою дуже перспективний нафтогазопошуковий об`єкт. Це підтверджується відкриттям у верхньокрейдових карбонатних та глинисто-карбонатних утвореннях промислових покладів нафти і газу на Серебрянській площі (Рівнинний Крим) та площі Шмідта (північно-західний шельф Чорного моря). 3 окремих свердловин припливи нафти і газу отримані на Октябрьській, Карлавській, Бакальській, Серебрянській, Первомайській площах (Рівнинний Крим) та Фланговій площі (шельф Чорного моря).

\section{ВИСНОВКИ}

Отже, нами було встановлено, що при дослідженнях карбонатних порід-колекторів літолого-петрографічні методи відіграють важливу роль. Вивчення цих порід у шліфах під мікроскопом дозволяє безпосередньо простежити характер їх пористості (загалом вторинної пористості і кавернозності) і тріщинуватості та обчислити вторинну відкриту пористість і параметри тріщинуватості. Традиційні ла- 
бораторні методи дослідження характеризують в основному міжзернову пористість і проникність карбонатних порід. А оскільки карбонати головним чином належать до колекторів тріщинуватого типу, їх фільтраційні властивості зумовлені системами тріщин, а ємність складають не тільки міжзернові пори, але і вторинні пустоти вилуговування. Це свідчить про практичне значення мікроскопічного дослідження карбонатних порід у шліфах [4].

Одночасно мікроскопічне вивчення дозволяє більш детально уточнити речовинний і мінеральний склад і структурні особливості. Такі дані складають основу розшифровки умов накопичення і процесів змінювання карбонатних порід, які здебільшого визначають та зумовлюють формування іх колекторських властивостей. Також при узагальненні наявних геологічних матеріалів літолого-петрографічні спостереження, серед яких дані мікроскопічного вивчення порід, дозволяють виконувати реконструкцію літолого-фаціальних і палеогеографічних умов утворення досліджуваних карбонатних відкладів [4].

Було встановлено, що хімічний склад карбонатних порід крейди є характерним для певних літологічних типів і залежить від їх віку. Різниця умов накопичення осадків на північно-західному шельфі Чорного моря стала причиною диференціації порід за хімічним та мінеральним вмістом.

Повсюдне знаходження бітумоїдів в осадовій товщі крейдового віку та їх збільшення вниз по розрізу на всій території шельфу становить практичний інтерес.

Також стало зрозумілим, що теригенна седиментація, яка впродовж першої половини крейдового періоду домінувала у Причорноморсько-Кримському шельфовому басейні у пізній крейді змінилася біогенним (карбонатним) осадконагромадженням. Подібна картина встановлена і для інших регіонів, зокрема для північної Атлантики, де пізньокрейдова частина розрізу відрізняється різким зменшенням теригенного скиду. Така закономірність крейдового седиментогенезу була зумовлена широким розвитком трансгресій у пізньокрейдовий час.

1. Богаец А.Т., Бондарчук Г.К., Леськив И.В. и др. Геология шельфа УсСР. Нефтегазоносность. - Киев: Наук. думка, 1986. - 152 с.

2. Богаец А.Т., Глушко В.В., Денега Б.И. и др. Прогноз поисков нефти и газа на юге УССР и на прилегающих акваторіях // Тр. УкрНИГРИ. - 1981. - Вып. 30. C. 220-231.

Institute of Geological Sciences NAS Ukraine, Kyiv, Ukraine Інститут геологічних наук НАН України, м. Київ, Україна
3. Цихоцкая Н.Н., Крочак М.Д. Карбонатные породы мела и палеогена северо-западного шельфа Черного моря. - Киев: 1987. - 56 с. - (Препр. / АН УССР. Ин-т геол. наук; 87-31).

4. Киркинская В.Н., Смехов Е.М. Карбонатне породы коллекторы нефти и газа. - Л.: Недра, 1981. - 255 с. 